\title{
Reptile diversity in the Duas Bocas Biological Reserve, Espírito Santo, southeastern Brazil
}

\author{
Jonathan Silva Cozer ${ }^{1,3}$; Juliane Pereira-Ribeiro ${ }^{2,4}$; Thais Meirelles Linause ${ }^{1,5}$; Atilla Colombo Ferreguetti ${ }^{2,6}$; \\ Helena de Godoy Bergallo ${ }^{2,7}$ \& Carlos Frederico Duarte da Rocha ${ }^{2,8}$
}

1 Universidade Federal do Espírito Santo (UFES), Departamento de Biologia. Vitória, ES, Brasil.

${ }^{2}$ Universidade do Estado do Rio de Janeiro (UERJ), Instituto de Biologia Roberto Alcântara Gomes (IBRAG), Departamento de Ecologia (DECOL). Rio de Janeiro, RJ, Brasil.

3 ORCID: http://orcid.org/0000-0003-4558-9990. E-mail: cozer.jonathan@gmail.com

${ }^{4}$ ORCID: http://orcid.org/0000-0002-0762-337X. E-mail: julianeribeiro25@gmail.com (corresponding author)

${ }^{5}$ ORCID: http://orcid.org/0000-0001-8186-0464. E-mail: thaismeirelles22@gmail.com

${ }^{6}$ ORCID: http://orcid.org/0000-0002-5139-8835. E-mail: atilla.ferreguetti@gmail.com

7 ORCID: http://orcid.org/0000-0001-9771-965X. E-mail: nena.bergallo@gmail.com

${ }^{8}$ ORCID: http://orcid.org/0000-0003-3000-1242. E-mail: cfdrocha@gmail.com

\begin{abstract}
The lack of information on the occurrence of species in a region limits the understanding of the composition and structure of the local community and, consequently, restricts the proposition of effective measures for species conservation. In this study, we researched the reptiles in the Duas Bocas Biological Reserve (DBBR), Espírito Santo, southeastern Brazil. We analyzed the parameters of the local community, such as richness, composition, and abundance of species. We conducted samplings from August 2017 to January 2019, through active search. We performed the samplings in nine standard plots of 250 meters in length. All individuals located in the plots or occasionally on the trails were registered. To evaluate sample effort to characterize the reptile community, we performed an accumulation curve of species, and to update the DBBR reptile list, we used as secondary data specimens deposited in collections and previously published studies. Considering primary and secondary data, we recorded 38 species, one chelonia, 13 lizards, and 24 snakes. Our study showed a richness of 15 additional species to the previous list of reptiles, increasing by about $40 \%$ the known richness to the area. We concluded that the DBBR holds a high richness of reptile species, representing $12 \%$ of the richness of reptiles of the Atlantic Forest and with a considerable number of endemic species in this biome. This suggests that the DBBR is an important forest fragment constituting a reservoir of the biodiversity of the reptiles of the Atlantic Forest.
\end{abstract}

Keywords. Atlantic Forest; Abundance; Reptilia; Richness; Rainforest.

\section{INTRODUCTION}

Reptiles are widely distributed and occur in different habitats, being present in all continents except for Antarctica (Di-Bernardo et al., 2003). Currently, approximately 11,000 reptile species are known in the world. Among these, 10,671 species are from squamate reptiles (Uetz \& Hošek, 2019). In a study aiming to categorize the conservation status of 1,500 reptile species distributed across the globe, about $20 \%$ of the species were categorized as endangered, with a high number of species currently under population decline occurring in tropical forests (Marques et al., 2010).

Habitat fragmentation, overexploitation (vegetable, mineral, and animal), and poaching, combined with the risks of global climate change and regional changes in precipitation have promoted a significant erosion of biodiversity (Joly et al.,
2014; Sinervo et al., 2010). Knowledge about species diversity across landscapes in different biomes is an important step for conservation, assisting in monitoring wildlife, especially in protected areas, and providing important information to understand the species diversity and distribution pattern (Zaher et al., 2011).

The lack of detailed information on reptile groups limits fine-scale understanding of the composition and structure of the local community and, consequently, restricts the proposition of effective measures for the conservation of the species of the group (Rocha et al., 2004). A recent study revealed that the patterns of richness and distribution of tetrapods might not characterize the patterns of the group of reptiles, especially lizards (Roll et al., 2017). In this study, Roll et al., used data from global reptile distribution to analyze reptile diversity patterns, and they iden- 
tified priority areas for the conservation of this group (e.g., the world's arid, grassland, and savannah habitats). Also, the study pointed out that the unique patterns of reptile diversity have important implications for their conservation (Roll et al., 2017). Thus, the proposition of specific strategies and actions for reptiles in a given region depends on prior knowledge of the parameters of communities in different areas, including understanding the distribution of reptile species in a larger geographical area (Rocha et al., 2009; Roll et al., 2017).

Duas Bocas Biological Reserve (DBBR) constitutes one of the largest remnants of the Atlantic Forest of the State of Espírito Santo (ES). It houses the protective forests of the water sources of the region of the municipality of Cariacica in ES (IEMA, 2018). DBBR has a high diversity of species, mainly due to the protection of the forests for the preservation of its springs and holding a considerable number of species that are currently in danger of extinction (Tonini et al., 2010). Despite the socio-environmental importance of the DBBR, there are currently few studies available on the local fauna and flora, and, particularly for the reptiles, the only information relies on a study that presented a previous list of non-volant tetrapods of the region (Tonini et al., 2010). In the present study, we sought to analyze the reptile local community parameters such as the richness, composition, and abundance and complement the list of reptiles species provided by Tonini et al. (2010) to provide subsidies to support future strategies and additional conservation actions for reptiles in the DBBR and surroundings remnants.

\section{MATERIAL AND METHODS}

\section{Study area}

Duas Bocas Biological Reserve (DBBR) is in the municipality of Cariacica $\left(20^{\circ} 14^{\prime} 04^{\prime \prime}\right.$ and $20^{\circ} 18^{\prime} 30^{\prime \prime} \mathrm{S}$, $40^{\circ} 28^{\prime} 01^{\prime \prime}$ and $40^{\circ} 32^{\prime} 07^{\prime \prime} \mathrm{W}$ ) in the State of Espírito Santo, Southeastern Brazil (Fig. 1). The Reserve has an area of 2,910 ha, with altitudes varying between 200 and $738 \mathrm{~m}$ a.s.l., constituting one of the most important forest fragments of the Atlantic Forest of the state of Espírito Santo, for harboring a rich and diverse fauna, with rare and endangered species (IEMA, 2018). In the reserve, the humid tropical climate predominates with relatively well-distributed rainfalls throughout the year. The relative air humidity is higher than $70 \%$, an average annual rainfall of approximately $1,500 \mathrm{~mm}$, and an average annual temperature of $22^{\circ} \mathrm{C}$ (Feitoza, 1986).

The DBBR has two main trails denominated the Represa Velha and Alto Alegre (Fig. 1). Represa Velha trail is 3,500 $\mathrm{m}$ long and between $202 \mathrm{~m}$ and $213 \mathrm{~m}$ a.s.l. It is composed of secondary forest areas, where banana, coffee, and pasture crops are introduced, besides a predominance of jackfruit (Artocarpus heterophyllus) (Boni

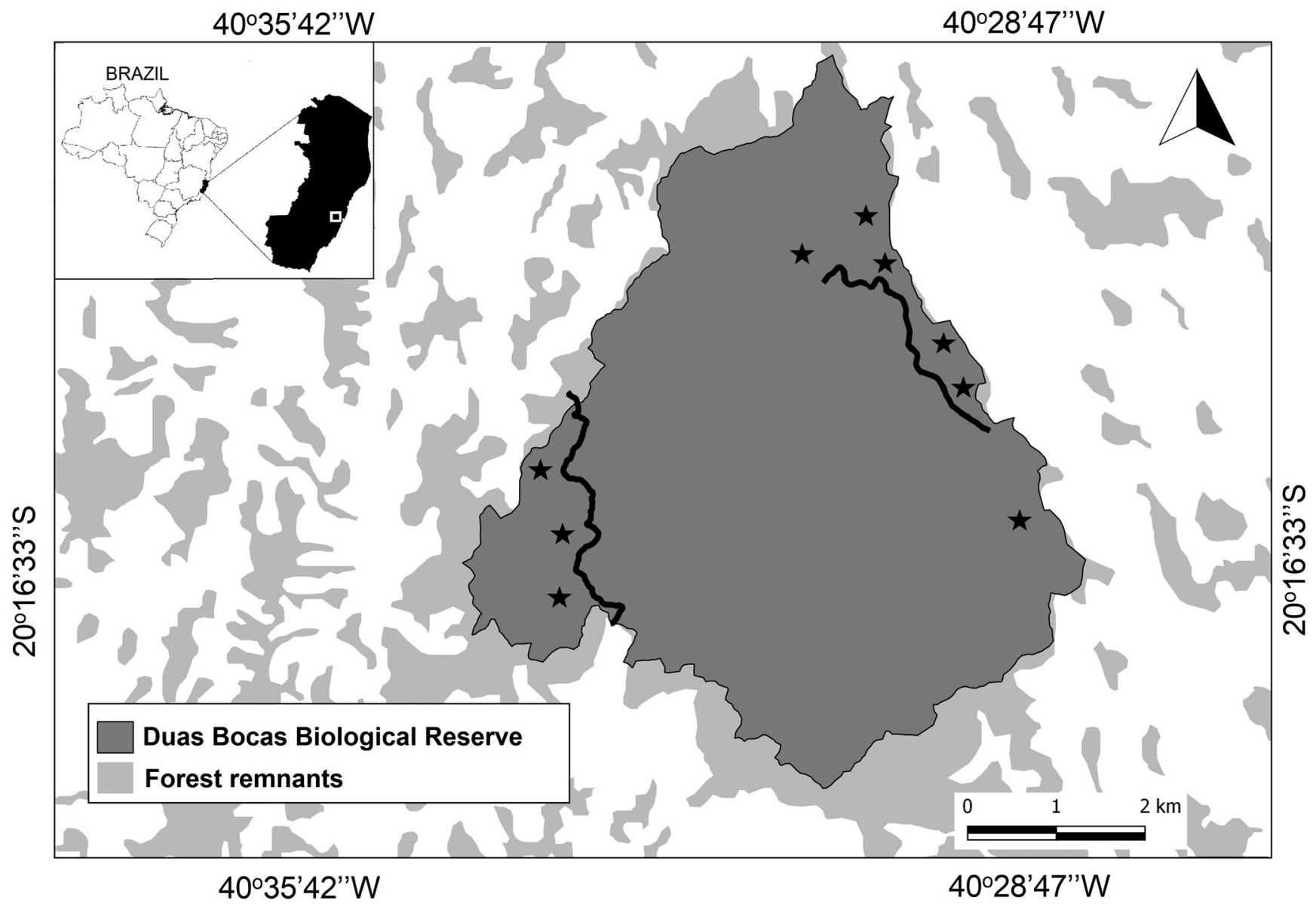

Figure 1. Location of Duas Bocas Biological Reserve, Cariacica, Espírito Santo, southeastern Brazil. Tracks and stars represent sampling areas of this study, with tracks representing the location of the trails and the stars representing the location of the plots. 
et al., 2009; Novelli, 2010). Alto Alegre trail is $4,000 \mathrm{~m}$ long and is $543 \mathrm{~m}$ a.s.l. It is composed of a forest with little evidence of disturbance, with a high density of large trees that provides a higher coverage of the leaf litter over the soil (Boni et al., 2009; Novelli, 2010).

\section{Data collection and analysis}

We sampled the reptiles for 18 consecutive months, from August 2017 to January 2019, with monthly campaigns of three to four days, through active search during the daytime periods (08:00-14:00 hours), twilight (17:00-18:00 hours), and nighttime (18:00-23:00 hours). Samplings were carried out in nine plots established along the forest and standardized with 250 meters in length, with a distance of at least 250 meters between adjacent plots. The active search of the reptiles was conducted by two observers (who remained the same throughout the study), who throughout each plot, sought individuals on the trees, on the leaf litter, on the trunks, or under tree bark, on logs fallen, on the edge of streams or under rocks, among other microhabitats. Each plot was sampled for 40 to 60 minutes, at least three times during the sampling period.

We recorded all the individuals observed at a distance of approximately five meters on each side of the plot (totaling a range of 10 meters of effective search). We noted the species and the time the individual was found. Besides the samplings in the plots, the individuals occasionally found in the two main DBBR trails (i.e., Represa Velha and Alto Alegre) were also recorded to estimate the richness and composition.

The captured animals were photographed, identified, and then released in the same locality. The species were identified based on the specific literature for each group, and with the aid of the Atlantic Forest snake guide (Marques et al., 2019), with confirmation by specialists, whenever necessary. When possible, one individual was collected per species (mainly when there was no previous record of the species for the area) as a specimen voucher (Permits IEMA 76433846 and SISBIO 56580-1). The individuals collected were euthanized with xylocaine anesthetic and fixed in $10 \%$ formalin solution, following standard procedures (CFMV, 2012). The specimens were deposited in the herpetological collection of the National Museum, Federal University of Rio de Janeiro (Appendix 1). Some individuals that were not collected were identified based on the characteristics of the species, through photography.

To evaluate sample sufficiency to characterize the DBBR reptile community, we conducted a rarefaction curve of species, which represented the observed and estimated richness based on sampling days. The expected richness curve corresponds to the richness of each sample calculated by one of the estimators (Bootstrap, Jackknife 1, and Chao 1). We obtained the model with estimators with 1,000 randomizations using the software EstimateS 9.0 (Colwell, 2013). We used the abundance of individuals as input to perform the analysis. Aiming to update the reptiles list in the DBBR, as secondary data, we used the species recorded in the study that inventoried the Tetrapods in the area (Tonini et al., 2010) and data of specimens deposited in scientific collections and included in the "Species Link" (www.splink.cria.org.br). To define endemism, we used Tozetti et al. (2017) and Costa \& Bérnils (2018).

\section{RESULTS}

In this study, we recorded 29 reptile species being one species of turtle, ten lizards, and 18 snakes (Table 1 , Figs. 2 and 3). Among the lizards, species of the family Gymnophthalmidae (two species) were predominant and, among the snakes, species of the families Dipsadidae (seven species) and Colubridae (four species) predominated. Our sampling efforts added 15 species to the DBBR list of reptiles, two lizards, and 13 snakes.

The estimated rarefaction curve of the species did not obtain asymptote, and the Bootstrap richness estimator showed the lowest standard deviation in relation to the observed richness. A maximum average of 36 species in total $(35.73 \pm 2.79)$ was also estimated with Bootstrap, while the other estimators showed higher richness and standard deviation (Jackknife $=45.21 \pm 4.65$, Chao $1=62.41 \pm 15.17$ ) (Fig. 4) .

In terms of abundance, for the 29 species recorded in the field samplings (primary data), we found a total of 93 individuals: one turtle, 53 lizards, and 39 snakes. Among the lizards, the most abundant species was Salvator merianae representing $39 \%$ of the individuals $(\mathrm{N}=20)$, followed by Leposoma scincoides representing $20 \%$ of the total number of individuals found $(\mathrm{N}=10)$. Among the snakes, the most abundant species was Chironius fuscus representing $23 \%$ of the recorded individuals ( $N=9$ ), followed by Bothrops jararaca with 13\% ( $\mathrm{N}=5)$.

Of the 38 reptile species that have a known occurrence in DBBR (considering primary and secondary data), 11 are endemic to the Atlantic Forest (Table 1). One species (Hydromedusa maximiliani) is currently classified as Vulnerable in the list of reptiles threatened with extinction in the state of Espírito Santo (DIO/ES, 2005; Almeida et al., 2007) and the Global List of Endangered Species (IUCN). None of the species we documented is classified as Threatened in the List of Endangered Brazilian Fauna (ICMBIO, 2018). Also, we recorded the occurrence of one exotic and invasive species of lizard (Hemidactylus mabouia).

There were changes concerning some previous records of reptiles for DBBR concerning secondary data: (i) the specimen identified as Micrurus corallinus, recorded by Tonini et al. (2010), had its identity subsequently revised as being Erythrolamprus aesculapii (information observed in the "Species Link" - MBLM 3787 - JFT 431). As a result, the $M$. corallinus specimen recorded in the present study constitutes the first record of the species for DBBR; (ii) the specimen identified as Taeniophallus bilineatus, recorded by Tonini et al. (2010), had its identity subsequently revised as being $T$. affinis (information observed in the "Species Link" - MBLM 3785 - JFT 458); (iii) Dipsas 
Table 1. List of reptile species recorded in the Duas Bocas Biological Reserve, Cariacica, Espírito Santo State, Southeastern Brazil. A = Abundance, $S D=S e c o n d a r y$ Data, $\mathrm{E}=$ Endemism, $\mathrm{AF}=$ Atlantic forest.

\begin{tabular}{lllll}
\hline & Taxa & A & Source & \\
\cline { 3 - 4 } & & This study & SD
\end{tabular}

\section{TESTUDINES}

Hydromedusa maximilliani (Mikan, 1820)**

\section{SQUAMATA}

\section{Gekkonidae}

Hemidactylus mabouia (Moreau de Jonnes, 1818)*

Phyllodactylidae

Gymnodactylus darwinii (Gray, 1845)

\section{Mabuyidae}

Psychosaura macrorhyncha (Hoge, 1947)

\section{Dactyloidae}

Dactyloa punctata (Daudin, 1802)

\section{Leiosauridae}

Enyalius brasiliensis (Lesson, 1828)

\section{Polychrotida}

Polychrus marmoratus (Linnaeus, 1758)*

\section{Tropiduridae}

Tropidurus torquatus (Wied-Neuwied, 1820)

\section{Anguidae}

Diploglossus fasciatus (Gray, 1831)

Ophiodes aff. striatus (Spix, 1824)

\section{Gymnophthalmidae}

Ecpleopus gaudichaudii Duméril \& Bibron, 1839

Heterodactylus imbricatus Spix, 1825

Leposoma scincoides Spix, 1825

\section{Teiidae}

Salvator merianae Duméril \& Bibron, 1839

\section{Leptotyphlopidae}

Trilepida salgueiroi (Amaral, 1955)*

\section{Boidae}

Boa constrictor Linnaeus, 1758

Corallus hortulanus (Linnaeus, 1758)*

Epicrates cenchria (Linnaeus, 1758)*

\section{Colubridae}

Chironius bicarinatus (Wied, 1820)

Chironius exoletus (Linnaeus, 1758)*

Chironius fuscus (Linnaeus, 1758)*

Oxybelis aeneus (Wagler, 1824)*

Spilotes sulphureus (Wagler, 1824)*

\section{Dipsadidae}

Dipsas neuwiedi (lhering, 1911)*

Dipsas sazimai Fernandes, Marques \& Argolo, 2010

9

Elapomorphus quinquelineatus (Raddi, 1820)

Erythrolamprus aesculapii (Linnaeus, 1766)

Erythrolamprus miliaris (Linnaeus, 1758)*

Erythrolamprus reginae (Linnaeus, 1758)

Erythrolamprus poecilogyrus (Wied, 1825)

Oxyrhopus formosus (Wied-Neuwied, 1820)

Oxyrhopus petolarius (Linnaeus, 1758)*

Pseudoboa nigra (Duméril, Bibron \& Duméril, 1854)*

Taeniophallus affinis (Günther, 1858)

Xenodon neuwiedii Günther, 1863

\section{Elapidae}

Micrurus corallinus (Merrem, 1820)*

\section{Viperidae}

Bothrops jararaca (Wied-Neuwied, 1824)

Bothrops jararacussu Lacerda, 1884
X

Tonini et al. (2010)

Tonini et al. (2010); Collection Data

Tonini et al. (2010); Collection Data

\section{Tonini et al. (2010); Collection Data}

Tonini et al. (2010); Collection Data Tonini et al. (2010); Collection Data

Tonini et al. (2010); Collection Data Tonini et al. (2010); Collection Data Tonini et al. (2010); Collection Data

Tonini et al. (2010); Collection Data

Tonini et al. (2010); Collection Data

Tonini et al. (2010); Collection Data

Tonini et al. (2010); Collection Data

AF

Collection Data

Tonini et al. (2010); Collection Data Tonini et al. (2010); Collection Data Tonini et al. (2010)

Collection Data

Tonini et al. (2010); Collection Data $\quad$ AF

* Species that represent new records for the studied area; ${ }^{* *}$ Classified as Vulnerable (IUCN and ES). 
catesbyi was removed from the previous list due to an error in the locality of the specimen used as a voucher in the first list of reptiles at the site. According to Costa \& Bérnils (2018), the specimen (IBSP 25393) mentioned by Tonini et al. (2010) refers to the individual collected in the location of Duas Bocas, in Amapá, and not in the Duas Bocas Biological Reserve, in Espírito Santo.

\section{DISCUSSION}

The records we obtained for the reptile fauna of the DBBR indicated, currently the occurrence of 38 species, being one turtle, 13 lizards, and 24 snakes, based on primary and secondary data. Thus, considering the full dataset (primary + secondary data), the number of registered species corroborates with the predicted richness for the area by the Bootstrap estimator (Fig. 4). We recorded a richness of species similar to those found in other studies with reptiles in the Atlantic Forest. For example, in a study on the herpetofauna of the Parque Estadual Turístico do Alto Ribeira, in the State of São Paulo, 31 reptile species were recorded, one species of turtle, 23 species of snakes, and seven species of lizards (Araújo et al., 2010). In another study on the herpetofauna of Ilha Grande, Rio de Janeiro, 40 reptile species were recorded, being 27 snakes, 11 lizards, one amphisbaenid, and one crocodilian (Rocha et al., 2018).

We added 15 reptile species to the previous list of non-volant tetrapods species for the area (Tonini et al., 2010), increasing the species richness known for the area by about $40 \%$. The species that had been added to DBBR reptile list were: Polychrus marmoratus, Hemidactylus mabouia, Corallus hortulanus, Epicrates cenchria, Chironius fuscus, C. exoletus, Oxybelis aeneus, Spilotes sulphureus, Dipsas neuwiedi, Elapomorphus quinquelineatus, Erythrolamprus miliaris, Oxyrhopus petolarius, Pseudoboa nigra, Trilepida salgueiroi, and Micrurus corallinus. Probably, this substantial increase in richness for the area results from that the samplings in the study
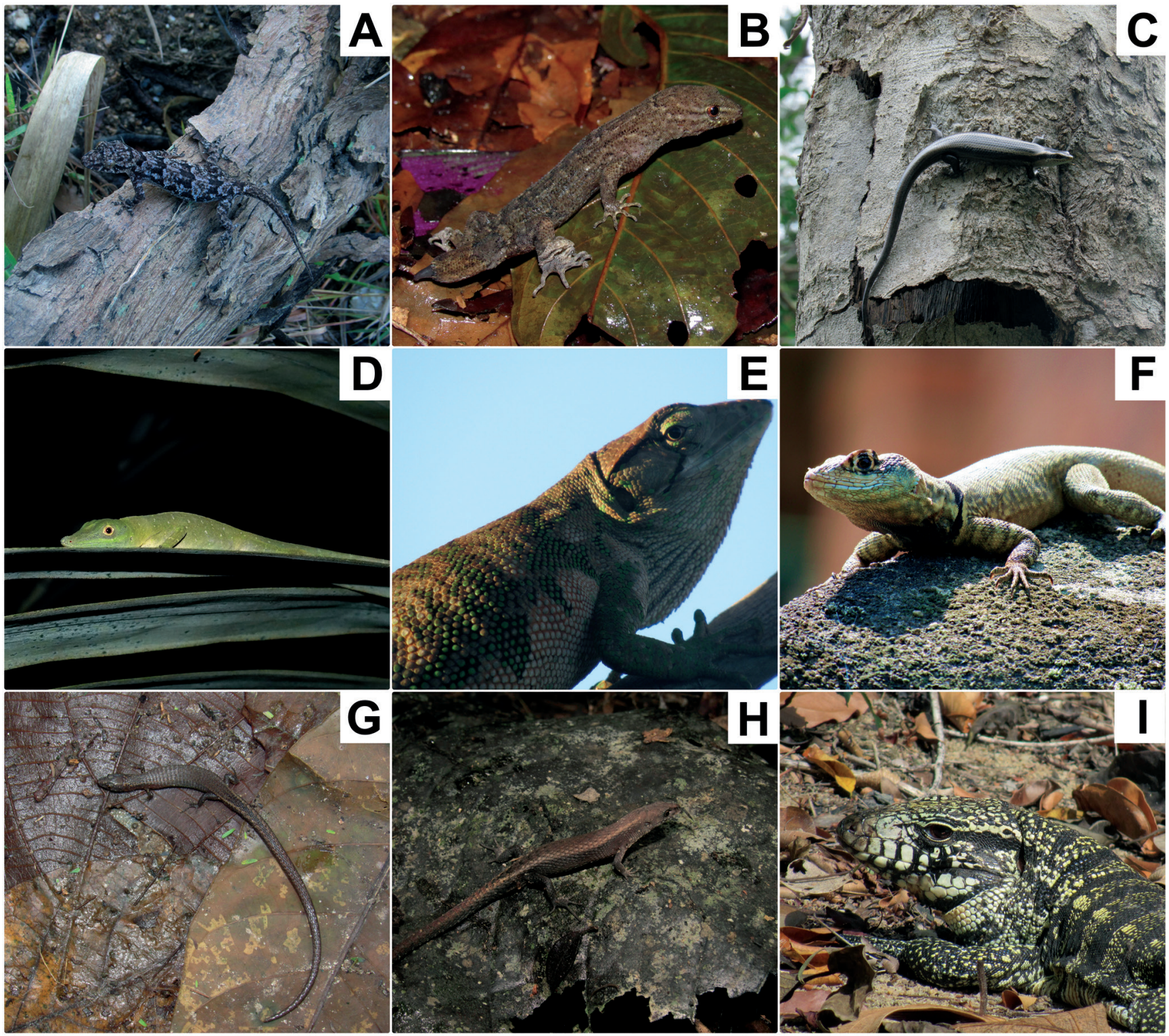

Figure 2. Examples of lizard species occurring in Duas Bocas Biological Reserve, Espírito Santo, Brazil: (A) Hemidactylus mabouia, (B) Gymnodactylus darwinii, (C) Psychosaura macrorhyncha, (D) Dactyloa punctata, (E) Polychrus marmoratus, (F) Tropidurus torquatus, (G) Ecpleopus gaudichaudii, (H) Leposoma scincoides, (I) Salvator merianae. 
by Tonini et al. (2010) were restricted to only part of the Reserve, in the town of Alto Alegre. Tonini et al. (2010) argued that other species should occur in the region, indicating that additional and longer-term studies would be needed. Also, the record of new species for the reptile list of the DBBR should have been favored by the method used, in which each plot was randomly distributed, with a standard distance defined between them to avoid spatial autocorrelation. Additionally, the sampled plots had been located in different areas in relation to the habitat structure, thus being able to maximize the number of species found (Magnusson et al., 2005).
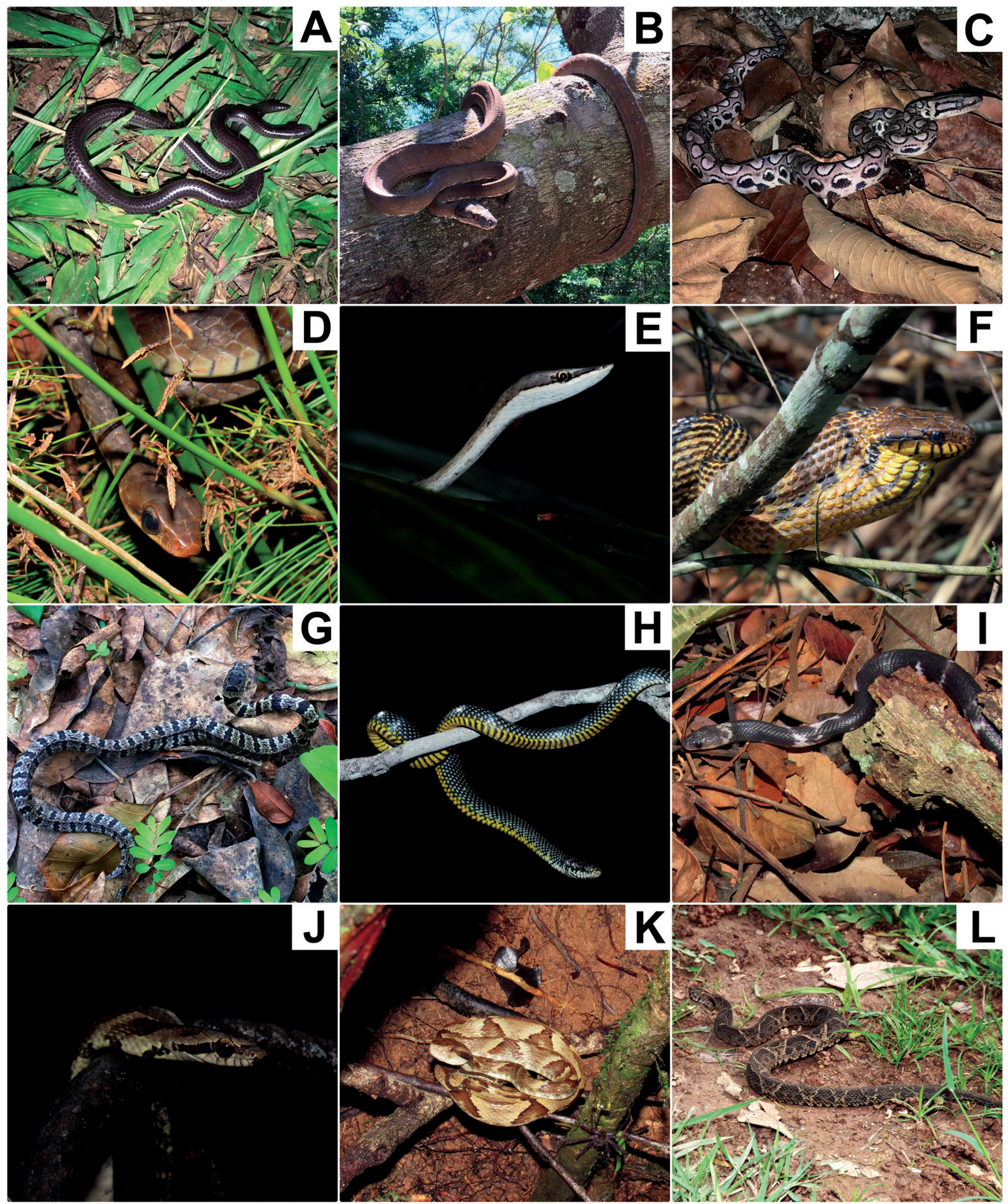

Figure 3. Examples of snake species occurring in Duas Bocas Biological Reserve, Espírito Santo, Brazil: (A) Trilepida salgueiroi, (B) Corallus hortulanus, (C) Epicrates cenchria, (D) Chironius fuscus, (E) Oxybelis aeneus, (F) Spilotes sulphureus, (G) Dipsas neuwiedi, (H) Erythrolamprus miliaris, (I) Pseudoboa nigra, (J) Xenodon neuwiedii, (K) Bothrops jararaca, (L) Bothrops jararacussu. 
The reptile richness currently recorded for the DBBR corresponds to $4.8 \%$ of the reptile species known to occur in Brazil and $12.6 \%$ of the known reptile species occurring in the Atlantic Forest Biome and about 30\% of the species that are currently registered in the state of Espírito Santo (Costa \& Bérnils, 2018). Besides, about 30\% of the species registered for DBBR are endemic to the Atlantic Forest biome (Tozetti et al., 2017). These figures underscore the importance of DBBR as an important reservoir of the biodiversity of Atlantic Forest reptiles.

The only exotic species registered in the reptile community of DBBR was the gekkonid lizard Hemidactylus mabouia, a species considered invasive in Brazil that is commonly associated with anthropic environments, although it can also occur in natural areas (Rocha et al., 2011; Oliveira et al., 2016). Recently, a study provided evidence of the advance of the invasion of $H$. mabouia in natural areas of coastal plains of Espírito Santo, with its occurrence being associated with human-modified habitats in natural environments (e.g., trails), especially those with some degree of vegetation opening (Oliveira et al., 2016). The nine individuals of $H$. mabouia registered in the present study were observed on the main trail of the Represa Velha area, close to the housing used to administer the Reserve. Due to the low number of individuals observed and considering that previous studies did not find this species at the site, we cannot make inferences about the species invasion in the area. However, studies for monitoring the species in the area are necessary, since the invasion of the species has already been observed in natural places with similar vegetation and altitude in the Atlantic Forest (Rocha et al., 2011; Almeida-Gomes et al., 2014).

The data showed that the most abundant species among the lizards was Salvator merianae. The abundance of $S$. merianae is probably related to the generalist habits of the species. It is known that these lizards have general habits, occurring in diverse habitats and being a significant component in reptile communities in different areas such as closed forests, forest fragments, and deforested areas (Werneck \& Colli, 2006; Bovendorp et al., 2008). It is a large diurnal lizard that occurs in most Brazilian biomes (Ferreguetti et al., 2018). In the Atlantic Forest, it is pres-

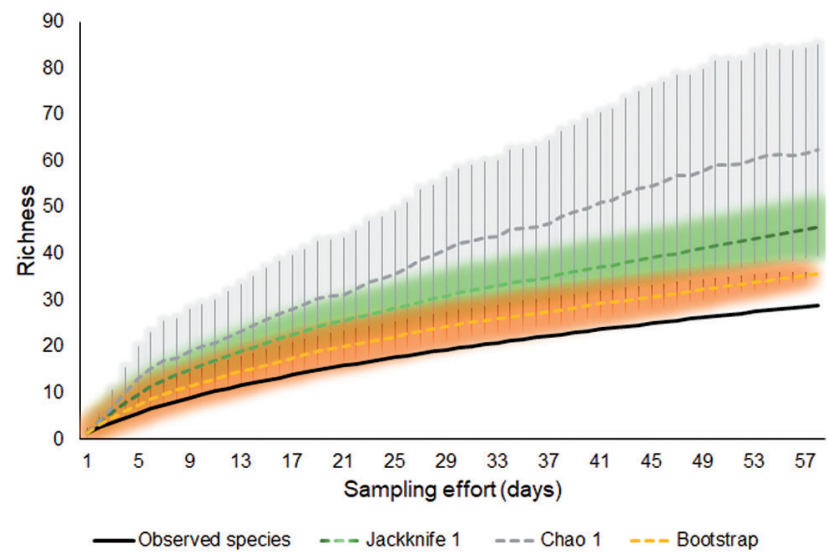

Figure 4. Accumulation curves of reptile species based on the sampling days in the Duas Bocas Biological Reserve, Espírito Santo, Brazil. The colored shaded area corresponds to the error bars associated with each estimator. ent in different forest remnants, having an omnivorous feeding that includes invertebrates, small vertebrates, eggs, and fruits (Castro \& Galetti, 2004).

We also found that the most abundant species among the snakes in DBBR was Chironius fuscus. The genus Chironius is endemic to the neotropical region (Dixon et al., 1993). In the Atlantic Forest, Chironius fuscus occurs in a wide range of habitats, and it is found in the state of Espírito Santo, Bahia, Rio de Janeiro, and São Paulo (Nascimento et al., 2013). Chironius species are usually diurnal, occurring in terrestrial and/or arboreal environments (Rojas-Runjaic \& Rivero, 2006), actively foraging with relative specificity for anurans in their diet, preferably terrestrial and nocturnal species. As C. fuscus is diurnal, it tends to capture their nocturnal prey at the time they are in their daytime shelters (Nascimento et al., 2013). Individuals were found in this study during the day at sites near water bodies, which may be the result of active foraging in search of anurans.

We conclude that DBBR holds many reptile species, with a considerable number of endemic species of the Atlantic Forest biome. This suggests that the DBBR is an important forest fragment constituting an important reservoir of the reptile biodiversity in the Atlantic Forest and for the conservation of the biodiversity of the state of Espírito Santo.

\section{ACKNOWLEDGMENTS}

This study is part of the results of the "Programa de Pesquisas em Biodiversidade e Ecossistemas (PPBio Mata Atlântica Network)" of Ministério de Ciência, Tecnologia, Inovação e Comunicação (MCTIC) and was supported by Conselho Nacional de Desenvolvimento Científico e Tecnológico (CNPq) (Process 457458/2012-7). The authors benefited from grants provided to HGB (process 307781/2014-3) and to CFDR (302974/2015-6 and 424473/2016-0) from CNPq and through "Cientistas do Nosso Estado" Program from FAPERJ to CFDR (process $E-26 / 102.765 .2012$ and $E-26 / 202.920 .2015)$ and to $H G B$ (process E-26/201.267.2014 and E-26/202.757/2017). This study was financed in part by the Coordenação de Aperfeiçoamento de Pessoal de Nível Superior - Brasil (CAPES) - Finance Code 001. To the Rufford Foundation for financial support for the project (ID 22439-1). To the Instituto Estadual de Meio Ambiente e Recursos Hídricos do Estado do Espírito (IEMA) and Instituto Chico Mendes de Conservação da Biodiversidade (ICMBIO) by research authorization (license 76433846 and 56580-1, respectively). We thank Thiago Marcial de Castro for his assistance with species identification. This study is part of the results of the project "Vivendo na Floresta: Conservação da biodiversidade capixaba".

\section{AUTHOR'S CONTRIBUTIONS}

All the authors actively participate in the discussion of the results, they reviewed and approved the final version of the paper. 


\section{REFERENCES}

Almeida, A.P.; Gasparini, J.L.; Abe, A.S.; Argolo, A.J.S.; Baptistotte, C.; Fernandes, R.; Rocha, C.F.D. \& Van-Sluys, M. 2007. Os Répteis Ameaçados de Extinção no Estado do Espírito Santo. In: Passamani, M. \& Mendes, S.L. (Eds.). Livro de Espécies Ameaçadas de Extinção no Espírito Santo. Vitória, IPEMA. p. 65-72.

Almeida-Gomes, M.; Siqueira, C.C.; Borges-Júnior, V.N.T.; Vrcibradic, D.; Fusinatto, L.A. \& Rocha, C.F.D. 2014. Herpetofauna da Reserva Ecológica de Guapiaçu (REGUA) e das áreas do entorno, no estado do Rio de Janeiro, Brasil. Biota Neotropica, 14: 1-15.

Araújo, C.O.; Condez, T.H. \& Bovo, R.P.; Centeno, F.C. \& Luiz, A.M. 2010. Amphibians and reptiles of the Parque Estadual Turístico do Alto Ribeira (PETAR), SP: an Atlantic Forest remnant of Southeastern Brazil. Biota Neotropica, 10: 257-274.

Boni, R.; Novelli, F.Z. \& Silva, A.G. 2009. Um alerta para os riscos de bioinvasão de jaqueiras, Artocarpus heterophyllus Lam., na Reserva Biológica Paulo Fraga Rodrigues, antiga Reserva Biológica Duas Bocas, no Espírito Santo, Sudeste do Brasil. Natureza online, 7:51-55.

Bovendorp, R.S.; Alvarez, A.D. \& Galetti, M. 2008. Density of the tegu lizard (Tupinambis merianae) and its role as nest predator at Anchieta Island, Brazil. Neotropical Biology and Conservation, 3: 9-12.

Castro, E.R. \& Galetti, M. 2004. Frugivoria e dispersão de sementes pelo lagarto teiú Tupinambis merianae (Reptilia: Teiidae). Papéis Avulsos de Zoologia, 44: 91-97.

Colwell, R.K. 2013. EstimateS, Version 9.1: Statistical estimation of species richness and shared species from samples. Software and User's Guide). Freeware published at: http://viceroy.eeb.uconn.edu/estimates.

Conselho Federal de Medicina Veterinária (CFMV). 2012. Guia Brasileiro de Boas Práticas Para a Eutanásia em Animais: Conceitos e Procedimentos. Resolução № 1000/2012 (Comissão de Ética, Bioética e Bem estar Animal, ed.). (FMV, Brazil.

Costa, H.C. \& Bérnils, R.S. 2018. Répteis do Brasil e suas Unidades Federativas: Lista de espécies. Herpetologia Brasileira, 7: 11-57.

Departamento de Imprensa Oficial do Espírito Santo (DI0/ES). 2005. Decreto 1499-R, de 13 de junho de 2005. Lista de fauna e flora ameaçadas de extinção no Estado do Espírito Santo. Diário Oficial do Estado Espírito Santo. Vitória, Brazil.

Di-Bernardo, M.; Borges-Martins, M. \& Oliveira, R.B. 2003. Répteis. In: Fontana C.S.; Bencke, G.A. \& Reis R.E. (Orgs.). Livro vermelho da fauna ameaçada de extinção no Rio Grande do Sul. Porto Alegre, EDIPUCRS. p. 165-188.

Dixon, J.R.; Wiest, J.A. \& Cei, J.M. 1993. Revision of the Neotropical snake genus Chironius Fitzinger (Serpentes, Colubridae). Torino, Museo Regionale di Scienze Naturali di Torino. 270p. (Monografie 13)

Feitoza, L.R. 1986. Carta agroclimática do Espírito Santo. Governo do Estado do Espírito Santo, Secretaria de Estado da Agricultura, Empresa Capixaba de Pesquisa Agropecuária-EMCAPA, Brazil.

Ferreguetti, A.C.; Pereira-Ribeiro, J.; Bergallo, H.G. \& Rocha, C.F.D. 2018. Abundance, density and activity of Salvator merianae (Reptilia: Teiidae) and the effect of poaching on the site occupancy by the lizard in an Atlantic Forest Reserve, Brazil. Austral Ecology, 43: 663-671.

Instituto Chico Mendes de Conservação da Biodiversidade (ICMBio). 2018. Volume IV - Répteis. In: Instituto Chico Mendes de Conservação da Biodiversidade (Org.). Livro Vermelho da Fauna Brasileira Ameaçada de Extinção. Brasília, ICMBio. 252p.

Instituto Estadual de Meio Ambiente e Recursos Hídricos (IEMA). 2018. Reserva Biológica Duas Bocas. Available at: https://iema.es.gov.br/ REBIO Duas Bocas. Access in: 03/03/2018.

Joly, C.A.; Metzger, J.P. \& Tabarelli, M. 2014. Experiences from the Brazilian Atlantic Forest: ecological findings and conservation initiatives. New Phytologist, 204: 459-473.
Magnusson, W.E.; Lima, A.P.; Luizão, R.; Luizão, F.; Costa, F.R.C.; Castilho, C.V. \& Kinupp, V.F. 2005. RAPELD: a modification of the Gentry method for biodiversity surveys in long-term ecological research sites. Biota Neotropica, 5: 19-24.

Marques, 0.A.V.; Eterovic A. \& Sazima, I. 2019. Serpentes da Mata Atlântica: guia ilustrado para as florestas costeiras do Brasil. São Paulo, Editora Ponto A. 319p.

Marques, 0.A.V.; Nogueira, C.; Martins, M. \& Sawaya, R.J. 2010. Impactos potenciais das mudanças propostas no Código Florestal Brasileiro sobre os répteis brasileiros. Biota Neotropica, 10: 39-42.

Nascimento, L.P.; Siqueira, D.M. \& Santos-Costa, M.C. 2013. Diet, reproduction, and sexual dimorphism in the vine snake, Chironius fuscus (Serpentes: (olubridae), from Brazilian Amazonia. South American Journal of Herpetology, 8: 168-174.

Novelli, F.Z. 2010. A Reserva Biológica de Duas Bocas e seus Vínculos à História da Conservação no Espírito Santo. Natureza Online, 8: 57-59.

Oliveira, J.C.; Winck, G.R.; Pereira-Ribeiro, J. \& Rocha, C.F.D. 2016. Antropogenic effect or niche preference? Contributions to the knowledge of Hemidactylus mabouia invasion in South America. North-Western Journal of Zoology, 12: 389-392.

Rocha, C.F.D.; Anjos, L.A. \& Bergallo, H.G. 2011. Conquering Brazil: the invasion by the exotic gekkonid lizard Hemidactylus mabouia (Squamata) in Brazilian natural environments. Zoologia, 28: 747-754.

Rocha, C.F.D.; Bergallo, H.G.; Alves, M.A.S. \& Van Sluys, M. 2009. Análise da distribuição da diversidade da fauna no Estado do Rio de Janeiro. In: Bergallo, H.G.; Fidalgo, E.C.C.; Rocha, C.F.D.; Uzêda, M.C.; Costa, M.B.; Alves, M.A.S.; Van Sluys, M.; Santos, M.A.; Costa, T.C.C. \& Cozzolino, A.C.R. (Orgs.). Estratégias e ações para a conservação da biodiversidade no Estado do Rio de Janeiro. Rio de Janeiro, Instituto Biomas. p. 111-126.

Rocha, C.F.D.; Bergallo, H.G.; Pombal Jr., J.P.; Geise, L.; Van-Sluys, M.; Fernandes, R. \& Caramaschi, U. 2004. Fauna de anfíbios, répteis e mamíferos do Estado do Rio de Janeiro, sudeste do Brasil. Publicações Avulsas do Museu Nacional, 10: 3-23.

Rocha, C.F.D.; Telles, F.B.D.S.; Vrcibradic, D. \& Nogueira-Costa, P. 2018. The Herpetofauna from Ilha Grande (Angra dos Reis, Rio de Janeiro, Brazil): updating species composition, richness, distribution and endemisms. Papéis Avulsos de Zoologia, 58: 1-12.

Rojas-Runjaic, F.J.M. \& Rivero, E.I. 2006. Reptilia, Squamata, Colubridae, Chironius exoletus: distribution extension, new state record. Check List, 2: 82-83.

Roll, U.; Feldman, A.; Novosolov, M.; Allison, A.; Bauer, A.M.; Bernard, R.; Böhm, M.; Castro-Herrera, F.; Chirio, L.; Collen, B.; Colli, G.R.; Dabool, L.; Das, I.; Doan, T.M.; Grismer, L.L.; Hoogmoed, M.; Itescu, Y.; Kraus, F.; LeBreton, M.; Lewin, A.; Martins, M.; Maza, E.; Meirte, D.; Nagy, Z.T.; Nogueira, C.C.; Pauwels, O.S.G.; Pincheira-Donoso, D.; Powney, G.D.; Sindaco, R.; Tallowin, O.J.S.; Torres-Carvajal, 0.; Trape, J.F.; Vidan, E.; Uetz, P.; Wagner, P.; Wang, Y.; Orme, C.D.L.; Grenyer, R. \& Meiri, S. 2017. The global distribution of tetrapods reveals a need for targeted reptile conservation. Nature Ecology \& Evolution, 1: 1677-1682.

Sinervo, B.; Mendez-De-La-Cruz, F.; Miles, D.B.; Heulin, B.; Bastiaans, E.; Villagrán-Santa Cruz, M.; Lara-Resendiz, R.; Martínez-Méndez, N.; Calderón-Espinosa, M.L.; Meza-Lázaro, R.N.; Gadsden, H.; Avila, L.J.; Morando, M.; Riva, I.J.; Sepulveda, P.V.; Rocha, C.F.D.; Ibargüengoytía, N.; Puntriano, C.A.; Massot, M.; Lepetz, V.; Oksanen, T.A.; Chapple, D.G.; Bauer, A.M.; Branch, W.R.; Clobert, J. \& Sites Jr., J.W. 2010. Erosion of lizard diversity by climate change and altered thermal niches. Science, 328: 894-899.

Tonini, J.F.R.; Carão, L.M.; Pinto, I.S.; Gasparini, J.L.; Leite, Y.L.R. \& Costa, L.P. 2010. Non-volant tetrapods from Reserva Biológica de Duas Bocas, State of Espírito Santo, Southeastern Brazil. Biota Neotropica, 10: 339-351. 
Tozetti, A.M.; Sawaya, R.J.; Molina, F.B.; Bérnils, R.S.; Barbo, F.E.; Leite, J.C.M.; Borges-Martins, M.; Recoder, R.; Junior, M.T.; Argôlo, A.J.S.; Morato, S.A.A. \& Rodrigues, M.T. 2017. Répteis. In: Monteiro-Filho, E.L.A. \& Conte, C.E. (Orgs.). Revisões em zoologia:Mata Atlântica. Curitiba, Editora UFPR. 490p. Uetz, P. \& Hošek, J. 2019. The Reptile Database. Available at: http://www. reptile-database.org/db-info/SpeciesStat.html. Access in: 20/03/2020.
Werneck, F.P. \& Colli, G.R. 2006. The lizard assemblage from seasonally dry tropical forest enclaves in the Cerrado biome, Brazil and its association with the Pleistocenic Arc. Journal of Biogeography, 33: 1983-1992.

Zaher, H.; Barbo, F.E.; Martínez, P.S.; Nogueira, C.; Rodrigues, M.T. \& Sawaya, R.J. 2011. Répteis do Estado de São Paulo: conhecimento atual e perspectivas. Biota Neotropica, 11: 67-81.

\section{APPENDIX 1}

Voucher specimens of taxa recorded during field samplings in Duas Bocas Biological Reserve, Espírito Santo, Brazil, in the period of August 2017 to January 2019. Specimens with field numeration (JSC) will be deposited later at the herpetological collection of the National Atlantic Forest Institute (INMA: Instituto Nacional da Mata Atlântica), in Santa Teresa, Espírito Santo. MNRJ: Museu Nacional, Universidade Federal do Rio de Janeiro.

\begin{tabular}{lc}
\hline \multicolumn{1}{c}{ Taxa } & Voucher \\
\hline Leposoma scincoides & MNRJ 27237 \\
Polychrus marmoratus & MNRJ 27194 \\
Hemidactylus mabouia & JSC020 \\
Chironius exoletus & MNRJ 27193 \\
Elapomorphus quinquelineatus & MNRJ 27199 \\
Epicrates cenchria & MNRJ 27201 \\
Erythrolamprus miliaris & MNRJ 27198 \\
Pseudoboa nigra & MNRJ 27200 \\
Trilepida salgueiroi & MNRJ 27196, MNRJ 27195 \\
Xenodon neuwiedii & MNRJ 27192 \\
Micrurus corallinus & JSC025 \\
Oxyrhopus petolarius & JSC028 \\
\hline
\end{tabular}

